\title{
Challenges for Technological Development in China's Industry
}

Foreign investors are the main providers of technology

\section{Cong Cao}

\section{OpenEdition}

\section{Journals}

Édition électronique

URL : http://journals.openedition.org/chinaperspectives/924

DOI : $10.4000 /$ chinaperspectives.924

ISSN : 1996-4617

\section{Éditeur}

Centre d'étude français sur la Chine contemporaine

Édition imprimée

Date de publication : 1 juillet 2004

ISSN : 2070-3449

\section{Référence électronique}

Cong Cao, «Challenges for Technological Development in China's Industry », China Perspectives [En ligne], 54 | July- August 2004, mis en ligne le 16 avril 2008, consulté le 28 octobre 2019. URL : http:// journals.openedition.org/chinaperspectives/924 ; DOI : 10.4000/chinaperspectives.924

Ce document a été généré automatiquement le 28 octobre 2019

(C) All rights reserved 


\section{Challenges for Technological Development in China's Industry}

Foreign investors are the main providers of technology

Cong Cao

1 Since the late 1970s, and especially during the 1990s, foreign direct investment (FDI) ${ }^{1}$ has to a large extent recast China's industrial base and upgraded its industrial technology ${ }^{2}$. In 2001, China became the country with the highest number of mobile phone subscribers with 145 million users, and its 179 million fixed phone lines were the second highest, next to the United States ${ }^{3}$. By 2010, if not earlier, and, after overtaking Japan in 2002, China is expected to overtake the United States to become the world's largest PC market ${ }^{4}$. The Internet, barely known in China until the mid-1990s, now has almost 80 million users 5 . Products "Made in China" have moved beyond toys, garments, and sneakers and include consumer electronics products and high-tech gadgets.

2 According to a recent United Nations report, China was the tenth largest high-tech exporting country in the world in 1998 to $1999^{6}$. In 2003, China's high-tech exports hit US $\$ 110.3$ billion, a more than 41 -fold increase over $1991^{7}$. Recently, China began using technology standards-notably the third-generation wireless standard TD-SCDMA (Time Division-Synchronous Code Division Multiple Access) and wireless encryption standard WAPI (Wired Authentication and Privacy Infrastructure)-as its technology policy instrument ${ }^{8}$. In twenty years, China has evolved from a closed and planned economy dominated by agriculture and heavy industry to an open economy driven by information, knowledge and skills.

3 Yet, whether Chinese industry and its high-tech sector can actually sustain growth remains a question. In fact, the Chinese technological reality is either not well known, or has been distorted or misunderstood. Being further integrated into the world economy since entering the WTO, China is facing fiercer international competition. The question is whether China will be able to develop an indigenous technological capability, in the near and medium term, to support its capacity to be competitive in the world markets.

Some examples in technological development in Chinese industry 
4 Although technological development seems a priority, Chinese firms encounter much difficulty in attaining sophistication in technology, mainly because they lack the necessary capabilities. This leads to price wars, patent infringements, and generally speaking, a difficulty upgrading to more sophisticated technology.

Continuous price wars: the television sector

5 China's television (TV) sector has recently attracted great attention. In November 2003, TCL, a consumer electronics producer in China, merged its TV manufacturing facilities with those of its French counterpart Thompson. The combined company, in which TCL holds a $67 \%$ share, is expected to ship 18 million TVs in 2004, thus coming top with $10 \%$ of the market. But in the meantime, TCL, along with fellow Chinese TV-makers Changhong, Konka and Xoceco, lost a US Department of Commerce anti-dumping case.

6 Using price as a weapon in the TV sector-anti-dumping being a countermeasure-is nothing new within China. Since 1996, the Chinese market has witnessed a series of TV price wars. In the name of defending the indigenous industry, price wars do help domestic firms gain market share over their foreign competitors. But the rising market share of some of the Chinese firms is most likely at the expense of their domestic peers or even themselves 9 . As price wars eat up their profit margins, many TV makers sell at lower-then-cost prices. In 2001, TV manufacturers saw the average profit level further reduced from $2.26 \%$ in 1999 to $2.05 \%$, and a nearly 3 billion yuan industry-wide loss ${ }^{10}$.

7 Prices are related to supply and demand. At a time when demand for TVs exceeded supply, local governments piled into the sector that had an artificially low market entry barrier, and then used a high degree of protection to ensure captive markets for local products and prevent unprofitable firms under their jurisdictions from being acquired. Then, overcapacity occurred as a result of duplicate economic activity at many Chinese firms that were set up just for the sake of creating employment for excess labour ${ }^{11}$. Moreover, China's TV manufacturers do not possess core technologies in very large-scale integrated circuits, tubes, displays, etc.

Infringement of foreign patents: the case of DVD players

8 In early 2002, China-made DVD players were impounded by customs in several European countries with the charge that their manufacturers had not paid for the patents used. Later, Philips, Sony and Pioneer waged a legal battle in the European Union court, pressuring Chinese DVD player manufacturers to pay royalties for the technologies. Initially, payment was requested at US\$20 per DVD machine, which the Chinese side claimed to be too high, given the sales price of a player being only US $\$ 90^{12}$. Through negotiation, these firms settled by agreeing to pay Philips, Sony and Pioneer US $\$ 5$. They also later reached agreements with other foreign companies on royalty payments: $4 \%$ of the sales price or US $\$ 4$, whichever is higher, for each player to NEC, Panasonic, Toshiba, JVC, Mitsubishi and Time Warner, US $\$ 10$ to DTS, US $\$ 4.95$ to Dolby Laboratories, and US\$2.5 to MPEG LA. Most recently, Thompson, the partner of TCL, requested a payment of US $\$ 1$ or US $\$ 1.5$, depending upon where the player is sold, China or abroad. With the number of DVD players made in China in 2003 being at least 50 million, the total payment amount was huge ${ }^{13}$.

Such incidents have been typical of the Chinese industry in the past decade. Multinational corporations (MNCs) have gradually moved the production of consumer electronics products from the United States and Japan to Singapore, South Korea, Taiwan and Hong Kong, and then to China and other countries with low labour costs; but they use critical technology patents as leverages and also focus on developing next- 
generation products or technology embodied in the existing products. China was supposed to have thus absorbed and assimilated such technology and to have gradually developed indigenous products and climbed the ladder of technological learning. Unfortunately, this has not happened; and therefore, located downstream of the global value chain, China has no choice but to continue to pay for the use of foreign technology. In the meantime, the homogenisation and commoditisation of these products have inevitably dragged Chinese firms into price competition. As such, their earning power has diminished significantly. TV manufacturer Changhong made the same profit from its sales of 6.94 million sets as Sony achieved through its sales of half a million sets ${ }^{14}$.

The phenomenon is not limited to the consumer electronics industry. Take Legend, China's largest PC manufacturer, as an example ${ }^{15}$. In 1998, it took over IBM to become the leader in China's PC market. But as Liu Chuanzhi, Legend's chairman, acknowledged, the company has merely played the role of a "mover" (banyungong) for foreign technology ${ }^{16}$. Similarly, having spent several billion dollars importing firstgeneration analog technology and second-generation global mobile communications (GSM) technology, China's mobile communications industry is still under the shadow of foreign technology. Although domestically manufactured mobile handsets held a market share of more than $50 \%$ in 2003, a dramatic increase from $5 \%$ in 2000, Motorola and Nokia have sold more phones to Chinese customers while many of those shipped by Bird, China's number one handset maker, are still sitting in warehouses or on store shelves ${ }^{17}$. Moreover, as few firms have devoted themselves to technological development, each and every mobile phone made in China contains critical components that have to be imported from abroad ${ }^{18}$. China's handset market has also been experiencing the familiar and disastrous price wars and the profit erosion ${ }^{19}$. And although the exact amount of money that China Unicom paid for Qualcomm's code division multiple access (CDMA) technology is unknown, it includes an entry fee, a software licence fee, and a fee linked to the number of subscribers or revenues. In addition, recently, Cisco Systems, the world's leading networking and communications manufacturer, accused China's switcher/router developer Huawei Technologies of patent infringement ${ }^{20}$. Foreseen areas of contention involving intellectual property rights in China include automobiles and digital TVs.

High-tech exports: comparative or competitive advantages?

11 A high-tech industry is, loosely speaking, one in which its success depends largely on its ability to keep up with rapid innovations in products or production processes, or both $^{21}$. Microelectronics, biotechnology, new materials, telecommunications, civilian aviation, robotics plus machine tools, and computers hardware and software are considered to be crucial to success amid current global competition ${ }^{22}$. Statistical classifications of high-tech industry typically rely on such indicators as the ratio of research and development (R\&D) expenditures to sales, the share of scientists and engineers in the labour force, and so on. The US Bureau of Census has adopted a separate classification code, "advanced technology" for products meeting the following criteria: the underlined technology is from a recognised high technology field (e.g., biotechnology, information technology); the technology used is leading-edge in that field ${ }^{23}$.

12 In China, a firm is to register and to be certified as high-tech only if it falls into the above-mentioned categories and meets the following requirements: at least $30 \%$ of its 
employees have college or higher level education, more than $5 \%$ of its sales is spent on $\mathrm{R} \& \mathrm{D}$, and more than $60 \%$ of its sales is related to technology services and high-tech products $^{24}$. High-tech in China's trade statistical reporting system until 1998 referred to computers and telecommunications, life science, aerospace and aeronautics, electronics, weapons, opto-electronics, computer integrated manufacturing, nuclear technology, biotechnology, and advanced materials. More recently, China has reported high-tech trade statistics under a new scheme, in which trade in weapons and nuclear technology are omitted while a new "other technology" category was introducedpresumably combined weapons and nuclear technology.

But a particular high-tech category could be further divided into different levels according to technological intensity and resulting profit and added value. Take PCs as an example. The first level is central processing units and core software, which has been dominated by the Wintel model (microprocessors from Intel and operating system and major applications packages from Microsoft). The second, including such key elements as integrated circuits, memory chips, and displayers, enjoys a higher level of risk as well as profit. The third and the lowest level is the assembling and manufacturing of terminal products, which involve a lower level of technological intensity but higher logistics costs and the advantages of which are reflected through economies of scale and localised sales and services ${ }^{25}$. China it seems has been stuck largely at the lowest level of the high-tech value chain.

One measure of the high-tech industry is trade statistics. However, comparable hightech trade data are difficult to locate not only because the "high-tech" definition is dynamic but also because it varies across countries. Here, we use both data from official Chinese sources and from the United States. The American data provide comparable trade statistics for economies in the world ${ }^{26}$ and allow the calculation of Trade Competitiveness (TC) ${ }^{27}$ and Revealed Comparative Advantage (RCA ${ }^{28}$.

15 Having experienced a steady increase, high-tech exports seem to be an important growth engine of the Chinese economy (Figure 1). As measured by Trade Competitiveness (TC), China's high-tech competitiveness in trade has been improved from -0.53 in 1991 to -0.04 in 2003 according to the Chinese data. If the data from the American source is used, however, China's TC in high-tech has declined slightly in recent years (Figure 2). Among the nine high-tech categories defined by the Chinese statistics, computer and telecommunications, aerospace, and advanced materials have gained international competitiveness, opto-electronics and the other technology category have lost competitive advantages, while electronics, computer-integrated manufacturing, life science, and biotechnology have not seen much change in their trade patterns. As a whole, computer-integrated manufacturing, other technology, aerospace, and electronics are the least competitive. 


\section{China's high-tech trade (US\$ billion)}

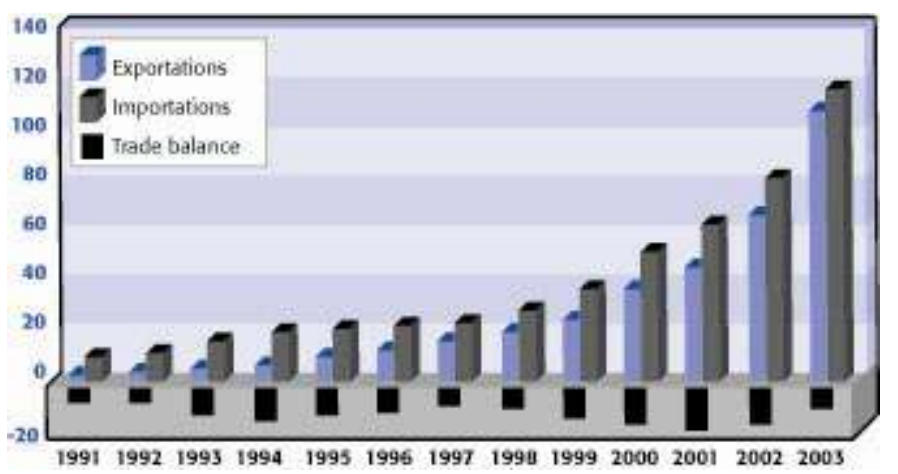

Source: National Bureau of Statistics and Ministry of Science and Technology (eds), China Statistical Yearbook on Science and Technology 2003, Peking, China Statistics Press, 2003.

\section{Competitiveness of China's high-tech trade}

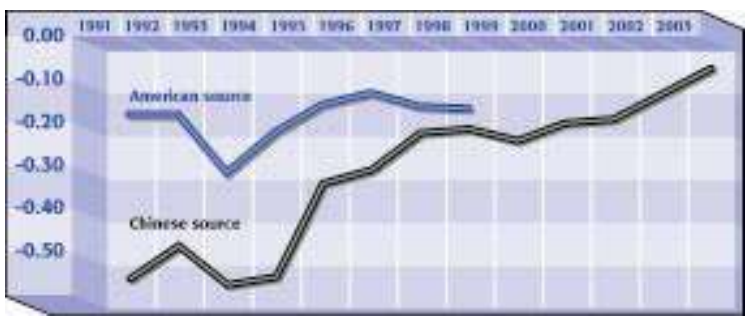

Sources: National Bureau of Statistics and Ministry of Science and Technology (eds.), China Statistical Yearbook on Science and Technology 2003, op. cit., and National Science Board, Science and Engineering Indicators 2002, Arlington, VA, National Science Foundation, 2002.

China's high-tech trade deficits have been fluctuating but increasing, which shows its high demand for and dependence upon advanced foreign technology. Although China has enjoyed a trade surplus in computer and telecommunications technology over the years, TC ( 0.39 for 2003) is less than the critical 0.5 threshold, suggesting that China is still behind in this the largest trade sector, which accounted for $83.3 \%$ of the high-tech exports in 2003. Trade deficits have been growing gradually in almost all other hightech sectors, especially in electronics and computer-integrated manufacturing, with an exception in biotechnology in which the trade surplus has been very small. Similar results could be obtained using data from the American source as well, with "office and computing machinery" and "communications equipment" gaining ground but still being far from the 0.5 reading, "drugs and medicines" suffering a dramatic loss, while "aerospace" experienced little change.

Here, I will use the Revealed Comparative Advantage (RCA) method to further measure how competitive China's particular high-tech fields are in the world (Figure 3). The "office and computing machinery" category had been the only high-tech sector in which China has gained significantly in the international markets recently, as indicated by a remarkable increase in its RCA from 0.076 , a very low competitiveness reading, in 1980 , to a strong trade competitiveness level of 1.30 in 1998. The RCA for "communications equipment" increased between 1980 and 1990 and declined thereafter, and the competitiveness of the "aerospace" industry had been improving, though not well. However, "drugs and medicines" witnessed its RCA erode significantly 
over the period in which comparable data are available-from a very competitive industry to one that was no longer competitive.

\section{Revealed comparative advantages of China's high-tech trade}

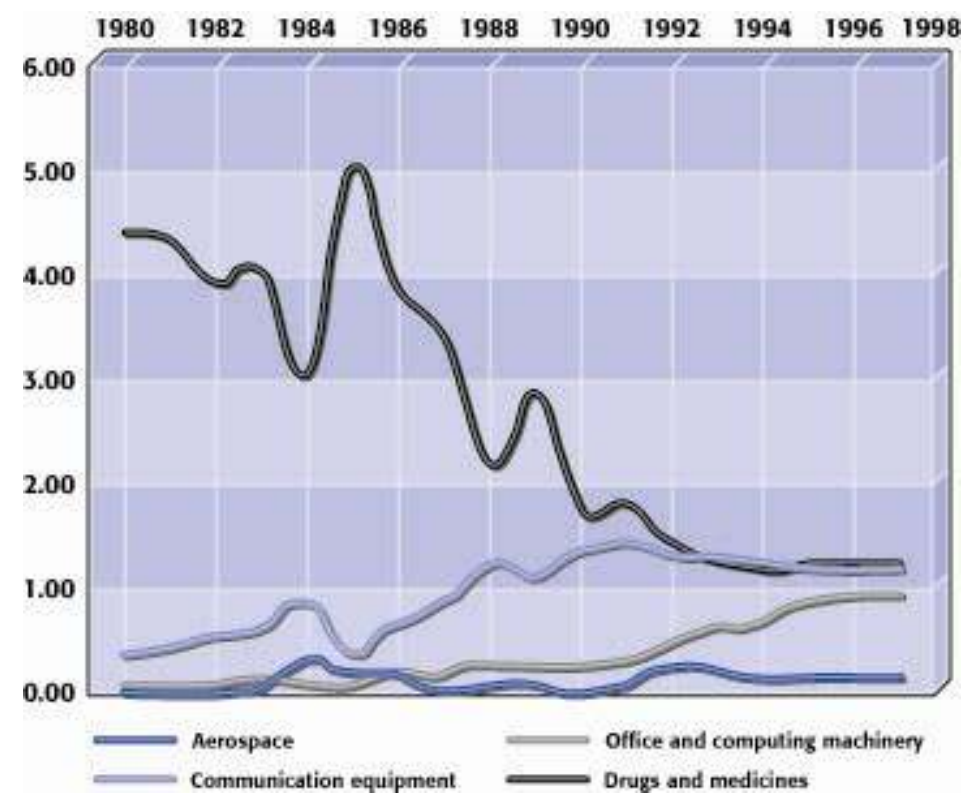

Source: National Science Board, Science and Engineering Indicators 2002, op. cit.

In the 1990s, China progressed in international high-tech exports. But what was behind these impressive trade statistics? First, while the export-oriented strategy has clearly shown results, processing and assembling with supplied materials from abroad for export accounted for about $90 \%$ of China's high-tech exports in $2002 .{ }^{29}$ There is doubt as to whether China has acquired much advanced technology in assembling, although in terms of technology content, FDI (foreign direct investment) in China in the early twenty-first century is presumably very different from the FDI it was receiving in 1985 or even in the early $1990 \mathrm{~s}^{30}$.

Second, the export-led high-tech industry has been based on low labour costs and imported foreign technologies or even components. China has become an important assembly line for products made using key high-tech parts from abroad with the addition of low-tech domestic components. The majority of Chinese exports are lowerend products involving basic processing and manufacturing techniques, while imports in general are much more sophisticated ${ }^{31}$. There has been a tendency among the world's leading MNCs, especially those in the information and communications technology (ICT) sector, to move their manufacturing facilities, or outsource production, to China, which, unfortunately, is not due to the nation's competitiveness in technology, but largely its comparative advantage in labour ${ }^{32}$. China has moved and will move steadily upmarket and anything-high- or low-tech-that requires many parts to be assembled in an efficient manner at low cost will find an attractive production base in China, which, in the purest sense of the term, is globalisation at work ${ }^{33}$. Being labour- rather than technology-intensive, those so-called "high-tech" gadgets have a profit margin of sometimes as low as $2-3 \%$. For example, Wanda, a wireless mouse manufactured by Logitech International SA, a Swiss-American company, sells in the United States for around US $\$ 40$, of which China takes a meagre US\$3 for wages, power, 
transport, and other overhead costs ${ }^{34}$. In a word, located at the lower end of the international division of labour, the nation has yet to achieve much in added-value and raise its competitive advantage significantly. This may also explain the discrepancy of trade statistics between the Chinese and American sources: products considered "hightech" in China may not be elsewhere.

Third, in sectors where China is enjoying a certain level of competitiveness, much of it has come from foreign-invested enterprises (sanzi qiye). In 2000, for example, $92.5 \%$ of computer systems and $96.4 \%$ of mobile communications equipments were exported by foreign-invested enterprises ${ }^{35}$. In 2002, wholly-owned foreign enterprises contributed $55.4 \%$ of China's high-tech exports, while state-owned enterprises (SOEs) have seen its portion declining year over year ${ }^{36}$. FDI to China is supposed to diffuse advanced technology to Chinese enterprises and make them technologically competitive; unfortunately, the high-tech exports statistics show a different picture.

The above analysis seems to indicate another reality about China's high-tech sector and industry: They have developed rapidly, but they are structurally risky-processing- and assembling-focused, low-end product-oriented and low value-added, and foreigninvested enterprise-led. China may make and export "high-tech" products in a large quantity, but may not enjoy higher added value as high-tech products are supposed to do, as a larger share of its companies' profits go to owners of core high technologies. The situation has not improved, and therefore the growth is probably unsustainable. To become a high-tech power, China has to move beyond the advantage that it offers in terms of labour in order to gain a competitive edge in a "cluster" of technologies to enable it to climb the technology value chain.

Broader problems

Since the early 1980s, in an effort to explore the Chinese way of technology diffusion, new technology enterprises spun off from China's research institutes and universities have competed with MNCs. Many of them have been successful because of their strong connection with the institutions from which they were spun off-Legend with the Chinese Academy of Sciences (CAS), Founder with Peking University, and so on. Although they were financially humble at their start, they had access to staff and facilities, and more importantly, could take advantage of research achievements made in these institutions-mainly the results of the state investment during the planned economy period ${ }^{37}$.

This strategy seems to have worked out well thus far. But further development of these technology enterprises is more unsure.

First, many of China's industrial firms have few financial resources to carry out innovative R\&D activities. Large- and medium-sized enterprises have spent on average $0.5 \%-0.8 \%$ of their sales on R\&D (Table 4$)^{38}$. According to a survey, firms within hightech parks spent an average $1.9 \%$ of their sales on R\&D, far below the $5 \%$ standard by the Chinese definition of a high-tech firm, as noted above, while those outside the parks merely $0.63 \%^{39}$. As enterprises have been cautious in their R\&D spending, a fair guess would be that the industry could not afford to spend money on technology ${ }^{40}$. 


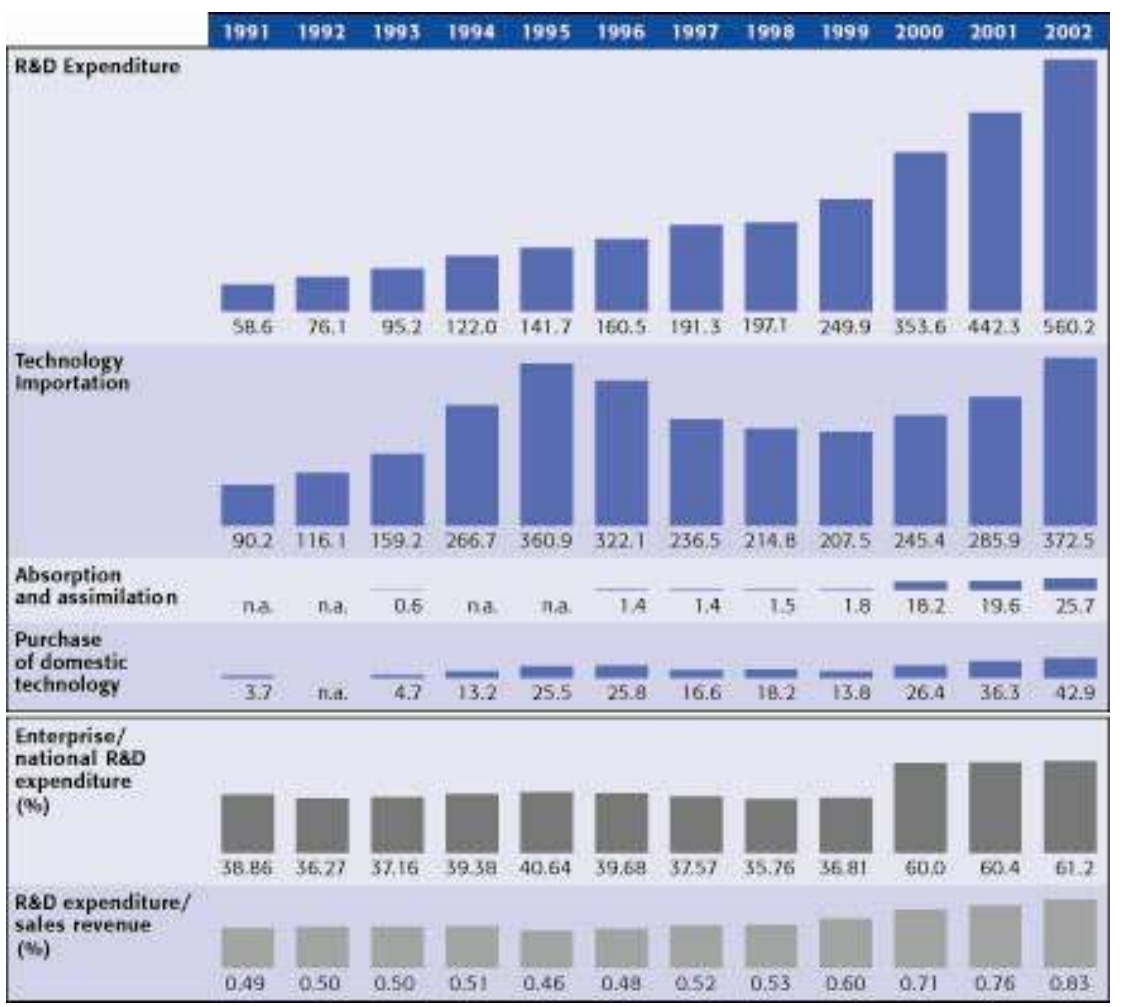

NB: n.a. = not available

Source: National Bureau of Statistics and Ministry of Science and Technology (eds.), China Statistical Yearbook on Science and Technology, Peking, China Statistics Press, various years.

Second, is the lack of qualified personnel because of a severe "brain drain" of Chinese talent to foreign countries as well as to foreign-invested enterprises in China. In 2002, in large- and medium-sized SOEs, personnel involved in technological development accounted for $5 \%$ of the total employees, and only about one-quarter of them had technological development units, representing a steady decline since the $1990 \mathrm{~s}^{41}$. As a result, even after acquiring designs from MNCs, SOEs still lack the depth of engineering expertise $e^{42}$.

Third, there is always the question of how this limited amount of resources is utilised. In pursuing quick profits, almost all the Chinese enterprises are keen to import foreign technology as the way to upgrade production technology, while in such purchases equipment dominates over software such as patents, know-how, blueprints, and so on. Between 1991 and 2002, a very limited amount of the spending on technology imports was used to obtain a technology licence, while $95 \%$ went on hardware. Large- and medium-sized enterprises spent more on technology importation than R\&D until 1999 (see Table 1). And once the equipment is imported, almost no financial resources are given to absorption, assimilation and innovation ${ }^{43}$, thus resulting in a vicious cycle of "importing, lagging behind, importing again, and lagging behind again".

Fourth, enterprises also lack interest in engaging domestic institutions of learning for $R \& D$ efforts. The reform of the science and technology system since the mid-1980s has to some extent activated the enthusiasm of researchers in these institutions (the supply side of technology), but enterprises (the demand side) have been reluctant to acquire technology from domestic sources. That is to say, the organisational rigidity between 
enterprises and institutions of learning have not been solved ${ }^{44}$. Such a problem may be due to the culture conflict between industry and academia. For example, in late 1998 when the Chinese Academy of Sciences (CAS) launched an ambitious Knowledge Innovation Programme to build the academy into the nation's centre in basic research and high-tech development, one of the measures was a reverse takeover of the CAS Institute of Computing Technology by Legend which spun off the institute 14 years ago. But the marriage ended in divorce as both sides had difficulty accommodating each other ${ }^{45}$.

Fifth, consequently, few Chinese enterprises own independent intellectual property rights in core technologies, as the data on patents suggest (Figures 5 and 6) ${ }^{46}$. Chinese firms seem to be more interested in utility model and design patents that link to unsubstantial modification, but lag far behind their foreign counterparts in invention patents. Since the 1990s, out of the more than 273,000 invention patent applications, only 47,452 (or $17.4 \%$ ) were from Chinese firms, which were granted 5,876. When Chinese enterprises have been busy importing technology, foreign entities, most likely MNCs, have grabbed $63.2 \%$ of total invention patents from China. Their expansion of technology reach in China may further restrain China's industrial technology. For example, China's pharmaceutical industry is built on modelling generic or off-patent drugs from abroad ${ }^{47}$; of the more than 1,000 core patents on colour TVs, none belong to China; $92 \%$ of the 426 third-generation (3G) mobile communications invention patent applications filed in China were from abroad, while China's Huawei Technologies ranked eighth with 23 applications, about a quarter of Samsung's ${ }^{48}$; in the petrochemicals industry, patent applications from MNCs accounted for $90 \%$ of the total; and in the aerospace industry, there are 30 times more invention patents filed by foreign firms than by domestic ones ${ }^{49}$. Of the invention patents received by China's Patent Administration between 1987 and 2002 in the areas of optical technology, photography and information storage, $75 \%, 81 \%$ and $89 \%$ were from foreigners ${ }^{50}$. The serious question is what the bottom line for the Chinese economy will be if MNCs continue to define the technological agenda and set the tone for the path of economic development.

29 As a result, a yawning gap remains between the finest corporations in China and the world. The nation has yet to come up with a China-created product as Japan in the early 1970s or South Korea in the $1990 \mathrm{~s}^{51}$, and not one of China's largest SOEs, or "national teams" as they are referred to, have become a globally competitive giant with a global market, a global brand, and a global procurement system ${ }^{52}$. These seem to be a bitter assessment of the Chinese industry's situation, but it is fair. 


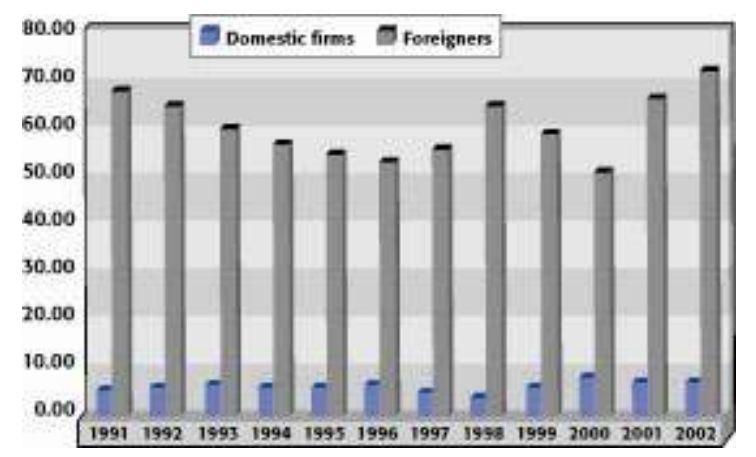

Source: National Bureau of Statistics and Ministry of Science and Technology (eds), China Statistical Yearbook on Science and Technology 2003, op. cit., p. 434.

Recent moves in China's industrial technological development

Entry to the WTO has brought more challenges and fiercer competition and Chinese firms are facing a crisis. The phasing out of many tariffs means the gradually eroded price advantage of domestic products and the domination of technology, quality and cost, rather than price in competition. Without access to updated technology and managerial know-how, the Chinese firms may lose their battle with their foreign competitors. In the meantime, MNCs have expanded their presence in China opening independent R\&D centres and collaborating with Chinese researchers. This is part of the global development strategy of the parent companies-being close to their Chinese operations and localising technology developed in the "home base"-so that their contribution to China's R\&D should not be exaggerated. But it is possible for MNCs to tap the high-quality researchers, even from domestic enterprises, so as to strengthen their position beyond the advantage of cheap labour in their production in China ${ }^{53}$. Under these circumstances, it is a matter of ultimate responsibility and survival, not choice, for China's domestic enterprises to upgrade their technologies and products on their own. In this regard, the Chinese government has also tried its best to stimulate innovation and provide policy guidance.

Increased R\&D activities in enterprises

In 2000, enterprise spending in China's R\&D exceeded $60 \%$ for the first time, implying that enterprises have become more important in research and innovation. A study of all high-tech firms in the Haidian district of Peking where the Zhongguancun Science Park is located finds that current sales revenue of the firm provides an important driving force for private R\&D expenditure $\mathrm{F}^{54}$. Between 2000 and 2003, the top 100 domestic electronics and information enterprises spent on average some $3 \%$ of annual sales revenue on R\&D (the number is not satisfying but promising), with telecoms equipment manufacturers Huawei Technologies, Datang Telecommunications, and Zhongxing Telecommunications leading the way, each devoting about $10 \%$ of the sales revenue to R\&D, well-qualified as high-tech firms even by international standards ${ }^{55}$. Nationwide, of the more than 10 million medium- and small-sized firms, 150,000 allocate more than $5 \%$ of sales to technological development ${ }^{56}$. 
6. Utility model and design patents granted in China

(\%)

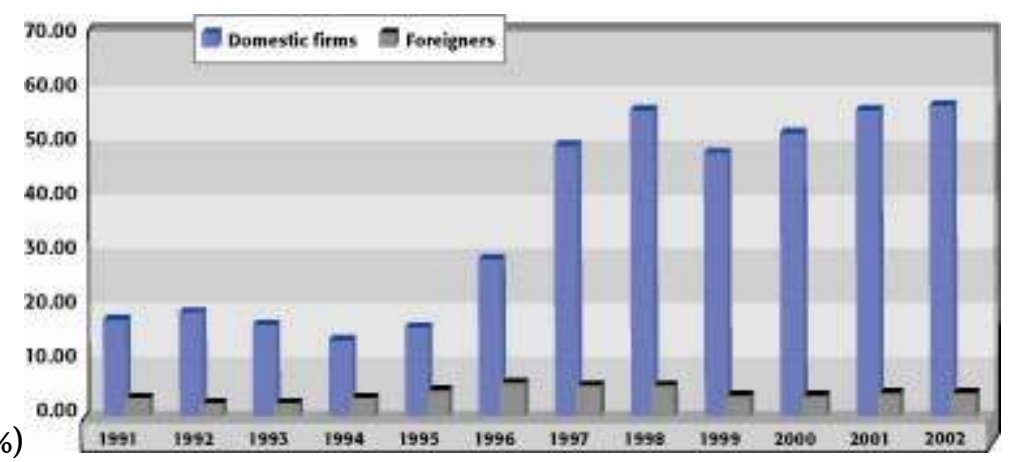

Source : National Bureau of Statistics and Ministry of Science and Technology (eds), China Statistical Yearbook on Science and Technology 2003, op. cit., p. 434.

Some of the most technology-intensive companies have taken the R\&D issue seriously by establishing or reinforcing their R\&D institutes ${ }^{57}$. For example, in Shenzhen, 477 (or 91.7\%) of the 521 R\&D institutes are associated with enterprises, and $90 \%$ of the R\&D personnel work in enterprises ${ }^{58}$. Legend, Founder, Chunlan, among others, have central research academies oriented towards developing process and product technologies and long-term technology strategies. Several Chinese corporations have also set up R\&D centres abroad as they expand internationally ${ }^{59}$.

Huawei is a case of point. Founded in 1988, it mandated in its charter to devote $10 \%$ of its sales revenue to $R \& D$, and increase the expenditure if necessary. Forty percent of the company's employees are engaged in R\&D, and the company is also involved in exploratory research ${ }^{60}$. In 2002, Huawei achieved a sales revenue of 17.2 billion yuan, of which 3 billion yuan (or 17.8\%) were spent on R\&D. The company now owns 686 patented technologies with $85 \%$ being invention patents, and its intelligence network won China's Scientific and Technological Progress Award in 2002, a rare but impressive achievement ${ }^{61}$.

The government's technology policy

The government has also aimed to stimulate the building-up of an indigenous technological capability in industry. The 1997 National Conference on Technological Innovation promoted the role of enterprises in the nation's R\&D activities. Immediately following the conference, the then State Economic and Trade Commission selected Baoshan Iron and Steel, Changhong, Jiangnan Shipbuilding, Northern China Pharmaceuticals (all SOEs), Hai'er (a collective), and Founder (a university spin-off) to experiment in technological innovation ${ }^{62}$. At the 1999 National Conference on Technological Innovation, the government further demanded that high-tech enterprises spend at least $5 \%$ of their annual sales on $R \& D^{63}$. The most recent policy measures include allowing $R \& D$ expenditure to be counted as cost, implementing a technology standard- and patent-focused strategy in enterprise innovation endeavours, and supporting software products "Made in China" in government procurements ${ }^{64}$.

In the information and communications technology (ICT) sectors, emphasis has been on developing China's semiconductor industry. Firms have been encouraged to develop central processing units (CPUs) used in certain consumer electronics products and mobile phone handsets. Attention has also been paid to design application specific integrated circuits (ASICs) used in ICT, a sector with advanced technological sophistication, wider usability as well as higher added value. China's computer industry 
has campaigned for the introduction and use of the open-source Linux operating system and related application software packages. Due to the government mandate, the Linux-based operating system and office applications developed by Chinese software companies have eroded Microsoft's dominance in software procurement, which signals not only the sensitivity, given the size of the procurement and strategic importance, but also the viability for these companies ${ }^{65}$. Under these circumstances, Microsoft was put on the defensive and agreed to invest 6.2 billion yuan to help develop China's software industry and China's e-government initiative ${ }^{66}$.

One of the high-profile technology policy measures is the so-called "technology standards" strategy by which China intends to formulate its own standards that leverage its large market in international competition ${ }^{67}$. China's participation in worldwide $3 \mathrm{G}$ wireless communications standard setting is one such example.

China's telecoms equipment manufacturing sector was among the first to open to global competition as well as the sector where domestic players have attained critical mass. China began its massive telecoms equipment manufacturing industry in the early 1980s. Initially, technology transfers through direct imports and Sino-foreign joint ventures played an important role. Through absorbing and assimilating foreign technology and most importantly indigenous R\&D efforts, Chinese firms, represented by Great Dragon, Datang, Zhongxing and Huawei ("JuDaZhongHua" according to the first characters of the firms' Chinese names), have gradually acquired advanced technology and accumulated technology capability to develop their own products. These firms employ a higher percentage of scientists and engineers with masters and doctorate degrees, and invest $10 \%$ or more of their sales revenue in $R \& \mathrm{D}^{68}$. They may still lack critical technology such as ASICs, and could acquire them through participating in the international division of labour-outsourcing those to foreign firms ${ }^{69}$; they are not in the same league with the world's big players either in size, technology, quality, or performance of the equipment, because most of the manufacturers are technology followers rather than innovators; and by the time they reverse-engineer the imported products and develop the manufacturing capability to imitate them, their international competitors will have introduced a successive generation. Nevertheless, because of their presence, foreign firms have to bow out of the low-end product market, or reduce prices for similar products sold in China. Domestic suppliers accounted for $43 \%$ of the stored programme-controlled central office switches in 2000 from none in 1982 (the statistics from another angle show why China's international competitiveness in communications exports increased as discussed above $)^{70}$.

Therefore, as China is, along with other countries moving towards the $3 \mathrm{G}$, it offers a domestically proposed and the International Telecommunications Union-approved standard-TD-SCDMA, jointly developed by China's Datang and Germany's Siemens-to compete with the cdma2000 standard by the US mobile network developer Qualcomm, the owner of key patents behind the code division multiple access (CDMA) standard, and the wideband CDMA (WCDMA) standard, also known as universal mobile telecommunications service (UMTS), from Europe. The Chinese government also allocated more radio spectrum to the home-grown TD-SCDMA standard than to its competitors-WCDMA and CDMA2000. Although the Chinese standard may not be as advanced as the other two standards and it may be premature to suggest that one of China's mobile operators would adopt the standard, the case itself-which may be 
labelled technonationalist-at least suggests that China's technical community has realised the importance of independent intellectual property rights and devoted its innovative capabilities to developing the most advanced technology. It remains to be seen whether the government initiative will lead to indigenous innovation at the firm level.

China's high-tech sector and industry have gained in vitality in the past two decades. But much of the development has been built on a massive infusion of foreign capital and FDI-embodied technology. It is quite understandable for a developing country like China to follow the technology importation path in its development. But for how long should China adopt such a development strategy?

Japan, Taiwan and South Korea all experienced the lag between technology importation and indigenous innovation. For example, when South Korea started heavy-andchemical-industry-led industrialisation in the 1960s, it chose to import foreign technology. Later on, through establishing the enterprise as the important player in the national innovation system and providing policy guidance, the country has seen endogenous innovation-driven development ${ }^{71}$. Korean firms have gradually moved from original equipment manufacturing (OEM) to own design manufacturing (ODM) and own brand manufacturing (OBM) so as to garnish much added value ${ }^{72}$. One would expect China to develop along the same trajectory.

In the meantime, the experiences of Asia's newly industrialised economies also suggest that it is not technology importation, but rather the lack of local absorptive capacity to assimilate, adapt, and improve imported technology, that leads to dependency on foreign technology; and heavy reliance on FDI as a means of technology transfer may to some extent reinforce such dependency ${ }^{73}$. China's economic development seems to be at a critical juncture as it faces the danger of dependency.

Notwithstanding the many advantages that would push China to overcome its current technological slump and to nurture a knowledge-based economy in the twenty-first century, the creation of new products and services resulting from innovations will be easily accommodated by a large domestic market that has started to be affluent, thus paving the way for even more innovations. However, the market advantage as well as comparative advantage in labour in many years to come could also discourage Chinese firms from attempting innovation. For one thing, combining its strengths in low-cost manufacturing and marketing channels with after-sales service capabilities, China has successfully overcome its weaknesses in quality, which probably gives firms less incentive to do well in the first place. The leverages of its market mean that China will likely continue having access to foreign technology. But only through enhanced technological capacity could China assume a leading position in the world market and enhance the position of domestic firms vis-à-vis those from the advanced industrialised nations $^{74}$.

China's technological capability in industry is still weak, which, plus the lack of urgency to pay attention to innovation among Chinese firms, makes an outlook that is not so optimistic. The current technology policy-playing the standards game-in fact signals its weaknesses, as China in the globalisation process has gained little in domestic capabilities. Of course, while it may be tempting to attribute the lack of technological innovation in Chinese enterprises to the bottleneck that inhibits or impedes China's industrial development, technology is a determining factor. If some of China's hightech enterprises at the very beginning were successful in exploiting and 
commercialising research results, they now run the risk of becoming so large and bureaucratic that they are unable to continue so being, as has happened before elsewhere $\mathrm{e}^{75}$. In the name of diversification and joining the "Fortune 500 Club", for example, Legend had expanded its business into system integration and services as well as areas in which the company does not have the expertise to compete with established firms, such as mobile phone handsets, digital cameras, management consulting, and even real estate ${ }^{76}$. It has turned out to be a painful move and the firm recently had to refocus on its PC business.

Emphasising the building of innovation and indigenous technological capability does not mean that institutional arrangements (industrial policy, venture capital, stock markets, etc.), ownership, and enterprise culture are secondary. In this regard, it remains to be seen whether the standards-centred technology approach would stimulate innovation, or protect less advanced domestic technology and hinder technological development.

Since the issue of technological development in industry boils down to development of local technological capability, then the final question has to be whether this capacity can be created by enterprises alone. The creation of this technological capability would be country, region or history specific. Many Silicon Valley firms have close relations with Stanford University; the Japanese example shows the construction of that capability began in the pre-Meiji era; and South Korea has emphasised the importance of the educational system and the construction of a structure that massively supports technology and engineering ${ }^{77}$. Of course, firm-specific characteristics also explain why some push towards technological development. While what may have been proved to be successful in other countries may not be so for China, although many of its high-tech enterprises did spin off from institutions of learning in the 1980s. With increased investment in R\&D but limitations in personnel, Chinese enterprises could develop technological capabilities by collaboration with universities and research institutes. In the meantime, the Chinese government has granted institutions of learning more leeway in transferring research results achieved through government funding. The government should also organise firms and institutions of learning to tackle common technology ${ }^{78}$.

\section{NOTES}

1. The author would like to thank Professor Richard P. Suttmeier for his critical and constructive comments on an early version of the paper.

2. Yasheng Huang argues that the inflow of FDI into China has in fact denied the growth opportunity of China's most efficient firms-non-government enterprises (minying qiye). See Selling China: Foreign Direct Investment during the Reform Era, Cambridge, Cambridge University Press, 2003. 
3. As of the end of 2003, China's mobile and fixed line users reached 269 million and 263 million respectively. See http://it.sohu.com/2004/01/19/61/article218696170.shtml (accessed on March 4th 2004).

4. http://msn-cnet.com.com/2100-1006_3-5091384.html (accessed on March 4th 2004).

5. http://www.cnnic.org.cn/html/Dir/2004/01/15/2080.htm (accessed on January 15th 2004).

6. United Nations Development Programme, Human Development Reports 2001: Making New Technologies Work for Human Development, New York, Oxford University Press, 2001, p. 42.

7. http://www.sts.org.cn/tjbg/jsmy/documents/2003/040330.htm (accessed on April 8th 2004).

8. For a discussion on that, see Richard P. Suttmeier and Yao Xianggui, "China's PostWTO Technology Policy: Standards, Software, and the Changing Nature of TechnoNationalism", NBR Special Report, No. 7, Seattle, WA, National Bureau of Asian Research, May 2004.

9. Changhong TV sets have been sold by their weights-a 29-inch one was sold at 1,575 yuan for its 52.5 kilograms, or 30 yuan per kilogram. See Zhongguo jingji shibao (China Economic Times), June 12th 2002.

10. Hong Kong iMail, April 26th 2002, p. 2.

11. Financial Times, October 19th 2001, p. 13.

12. Beijing qingnianbao (Beijing Youth Daily), March 11th 2002.

13. http://tech.sina.com.cn/it/2004-03-11/0712303633.shtml (accessed on March 11th 2004).

14. Financial Times, October 19th 2001, p. 13.

15. Although its Chinese name is still Liangxiang, Legend changed its English name to "Lenova" recently.

16. Fang Zhou, Guo Tianxiang, and Tian Yishan, Jinggao weiji: Zhongguo jiaru Shijie Maoyi Zhuzhi qianxi (Crisis Warning: Self Examination of Chinese CEO on the Eve of China's WTO Accession), Kunming, Yunnan renmin chubanshe, 2001, p. 45.

17. http://www.emtchina.com/eNews/emt_200302a.htm (accessed on March 5th 2004); and Evan Ramstad, "Amid Tech Boom, Chinese Stalwarts Scrape for Gains", Asian Wall Street Journal, February 27th-29th 2004, p. A1 and p. A8.

18. Ershiyi shiji jingji daobao (21st Century Economic News), December 30th 2002 and January 10 th 2003.

19. See, for example, Shichang bao (Market News), September 27th 2003, and Zhongguo gongshang shibao (China Business Times), February 11th 2004.

20. Bruce Einhorn, “China: Too Fast a Learner?", BusinessWeek, February 3rd 2003.

21. For a survey and discussion on the analysis of high-tech trade statistics, see J. A. D. Holbrook, "High-Tech Trade Pattern Analysis: Its Use and Application for Industry Competitiveness Response and Government Policy Development", CPROST Report \# 95-11, Ottawa, The Canadian Advanced Technology Association/Industry Canada Workshop on High-Tech Trade Statistics, 1995.

22. Lester C. Thurow, Head to Head: The Coming Economic Battle among Japan, Europe, and America, New York, William Morrow, 1992.

23. Robert H. McGuckin, Thomas A. Abbott, III, Paul E. Herrick, and Leroy Norfolk, "Measuring the Trade Balance in Advanced Technology", Center for Economic Studies Report \# 89-11, Washington, U.S. Bureau of Census, 1989; U.S. Bureau of Census, "U.S. 
International Trade in Goods and Services: Information on Goods and Services", at http://www.census.gov/foreign-trade/Press-elease/current_press_release/explain.txt (accessed on November 15th 2001); and John Sullivan Wilson, "The U.S. 1982-1993 Performance in Advanced Technology Trade", Challenge, No. 1, 1994, pp. 11-16.

24. Ministry of Science and Technology, "Guojia gaoxin jishu chanye kaifaqu gaoxin jishu qiye rending diaojian he banfa (Conditions and Methods of Certifying High- and New-Technology Enterprises in National High- and New-Tech Industrial Development Zones), in Ministry of Science and Technology (comp.), Zhongguo jishu chuangxin zhengce (Policies on Technological Innovation in China), Peking, Kexue jishu wenxian chubanshe, 2000, pp. 78-79.

25. Yuko Arayama and Panos Mourdoukoutas, China against Herself: Innovation or Imitation in Global Business?, Westport, CT, Quorum Books, 1999, p. 107.

26. The data are compiled by the U.S. National Science Foundation from the WEFA/ICF World Industry Service database. See National Science Board, Science and Engineering Indicators 2002, Arlington, VA, National Science Foundation, 2002, Appendix Table 6-1, World industry and trade data for selected countries or economies and industries: 1980-98.

27. Trade competitiveness (TC) measures the share of a nation's difference in exports and imports in the nation's trade: $T C=(X-M) /(X+M)$ where $X$ is nation's exports, and $M$ is nation's imports. A positive TC displays a competitiveness of a nation's good, with a greater than 0.5 reading meaning comparative advantage and a less than -0.5 reading comparative disadvantage.

28. Revealed comparative advantage (RCA) measures a nation's share in world exports of a good in the nation's share of total world exports:

$R C A_{j}=\left(X_{j} / X_{w j}\right) /\left(X_{t} / X_{w t}\right)$

where $X_{j}$ is a nation's exports of good $\mathrm{j}, X_{w j}$ is world's total exports of good $\mathrm{j}, X_{t}$ is a nation's total exports, and $X_{w t}$ is world's total exports. A greater than 2.5 RCA measure demonstrates that a nation has a very strong competitive edge in producing and trading a good, a reading between 1.25 and 2.5 means a strong competitiveness of a nation in a good, and a lower than 0.8 RCA index signifies that the nation is less competitive in its particular product. See Bela Balassa, "Trade Liberalization and 'Revealed' Comparative Advantage”, The Manchester School of Economics and Social Studies, Vol. 33, No. 2, 1965, pp. 99-123.

29. http://www.moftec.gov.cn (accessed on June 20th 2002).

30. For a similar finding through using a different set of international trade statistics, see Françoise Lemoine and Deniz Unal-Kesenci, "Assembly Trade and Technology Transfer: The Case of China", World Development, Vol. 32, No. 5, 2004, pp. 829-850. 31. Denis Fred Simon, "The Microelectronics Industry Crosses a Critical Threshold", China Business Review, Vol. 28, No. 6, 2001, pp. 8-20.

32. There are conflicting views towards China's comparative advantage in labour. Some indicate that such a situation is expected to continue for at least ten years, given China's larger pool of cheap labour from coastal to the inner regions. Asian Wall street Journal, March 15th-17th 2001, p. 1 and p. 8. Others think that China may lose such a comparative advantage because in some of the Chinese cities labour costs are as high as in some South-East Asian countries. Asian Wall Street Journal, December 30th 2002, pp.

A1-A2.

33. Joe Studwell, The China Dream: The Elusive Quest for the Great Untapped Market on Earth, London, Profile Books, 2002, p. 225. 
34. Andrew Higgins, "Symbiotic Ties to China Are a Boon and a Burden for the American Economy”, Asian Wall Street Journal, February 2nd 2004, p. A1 and p. A5B. 35. Jiang Xiaojuan, "Zhongguo de waizi jingji dui zhengzhang, jiegou shengji he jingzhengli de gongxian" (Contributions of Foreign Invested Enterprises in China to Local Economic Growth, Structural Upgrading and Competitiveness), Zhongguo shehui kexue (Social Sciences in China), No. 6, 2002, pp. 4-14.

36. http://www.moftec.gov.cn (accessed on June 20th 2002).

37. Qiwen Lu, China's Leap into the Information Age: Innovation and Organization in the Computer Industry, New York, Oxford University Press, 2000. Adam Segal, Digital Dragon. High-Technology Enterprises in China, Cornell University Press, 2003.

38. National Bureau of Statistics and Ministry of Science and Technology (ed.), China Statistical Yearbook on Science and Technology 2003, Peking, China Statistics Press, 2003, pp. 94-95.

39. http://www.china.org.cn/chinese (accessed on June 8th 2002).

40. One may argue that given its complex, uncertain, prolonged, and even risky nature, R\&D drawing an increased expenditure does not guarantee an immediate return to the investment or an increase in the firms' competitiveness. See Sanjaya Lall, "Technological Change and Industrialization in the Asian Newly Industrializing Economies: Achievements and Challenges", in Linsu Kim and Richard R. Nelson (eds.), Technology, Learning, \& Innovation, New York, Cambridge University, 2000, pp. 13-68. For a recent news report on the Japanese case, see “Japan Asks Why More Yen Don't Yield More Products", Science, Vol. 296, May 17th 2002, pp. 1 230- 231.

One may also argue that Dell has not relied on technology to become the world's largest PC manufacturer. The fact of the matter is that in the United States there are Intel, Microsoft, Hewlett-Packard, and many other technology-intensive firms, while Chinese high-tech firms such as Legend, Founder, Huawei, and so on are mandated to become technologically innovative.

41. China Statistical Yearbook on Science and Technology 2003, op. cit., pp. 94-95.

42. Kathryn Kranhold, "China Makes Power Play to Score Technology from Foreign Partners", Asian Wall Street Journal, February 26th 2004, p. A1 and p. A7.

43. An analysis of the Chinese statistics indicates that imported technologies are more likely to lead to market success in new product sales through their absorption. See Yifei Sun, "Sources of Innovation in China's Manufacturing Sector: Imported or In-house Developed?", Environment and Planning A, Vol. 34, No. 6, 2002, pp. 1 059-1 072.

44. For the structural difficulties that China needs to overcome in order to respond to the innovation challenge, especially the danwei effect, referring to the fact that the work unit is still very much the unit of reference of the governments (local and national) as well as the companies themselves, see Rigas Arvanitis, Pierre Miège, and Zhao Wei, "A Fresh Look at the Development of a Market Economy in China," China Perspectives, No. 48, July-August 2003, pp. 51-62.

45. Jishuanji shijie (China ComputerWorld), No. 1, January 3rd 2000, pp. A17-A24.

46. Although the economy has been struggling worldwide, one would never know it looking at the booming patent industry, especially in information technology and telecommunications, in the United States. See Erika Jonietz, "Economic Bust, Patent Boom", Technology Review, May 2002, pp. 71-77.

47. Recently, China issued new regulations on new medicines approvals. According to these regulations, a new medicine is defined as one that is making a first appearance in China. See Beijing xiandai shangbao (Beijing Business Daily), December 26th 2002, p. 5. 
48. Renmin ribao - Huanan xinwen (People's Daily • Southern China News), June 21st 2002, p. 1.

49. Jingji guanchabao (The Economic Observer), April 22nd 2002, p. 1.

50. http://www.blogchina.com/new/display/24128.html (accessed on February 26th 2004).

51. http://peopledaily.com.cn/GB/jinji (accessed on March 23rd 2002); Arayama and Mourdoukoutas, China against herself, p. 8.

52. Peter Nolan, "China and the Global Business Revolution", Cambridge Journal of Economics, Vol. 26, No. 1, 2002, pp. 119-137; Evaluation Association for China's Enterprises (comp.), Shiji zhijiao de Zhongguo daxing gongye qiye (China's Large Industrial Enterprises at the Turn of the Century), Peking, Jingji ribao chubanshe, 2000.

53. For a discussion on the creation of productive systems in China, see Arvanitis, Miège, and Zhao, op. cit.

54. Albert Guangzhou Hu, “Ownership, Government R\&D, Private R\&D, and Productivity in Chinese Industry", Journal of Comparative Economics, Vol. 29, No. 1, 2001, pp. 136-157.

55. http://www.mii.gov.cn (assessed on June 10th 2003).

56. Kexue shibao (Science Times), March 11th 2002.

57. Beijing qingnian bao (Beijing Youth Daily), March 22nd 1999, p. 6.

58. Yang Shenghua, Zhongguo: Chuangxin shengchun (China: Survival Through Innovation), Guangzhou, Huacheng Press, 2000, p. 60.

59. Research Group, Zhongguo keji fazhan yanjiu baogao 2000: Kexue jishu de quanqiuhua yu Zhongguo mianling de tiaozhan (A Research Report on China's S\&T Development 2000: The Globalization of Science and Technology and Its Challenges for China), Peking, Social Science Literature Press, 2000, p. 298.

60. Yang, Zhongguo: Chuangxin shengchun, op. cit., p. 253 and p. 262.

61. http://www.huawei.com.cn/about/zhishi.shtml (accessed on April 16th 2004).

62. Yang, Zhongguo: Chuangxin shengchun, op. cit., p. 50.

63. Ministry of Science and Technology (comp.), Zhongguo jishu chuangxin zhengce, op. cit., pp. 1-9.

64. Kexue shibao (Science Times), March 13th 2002; Zhongguo jingji shibao (China Economic Times), May 27th 2002; http://tech.sina.com.cn/it (accessed on May 28th 2002); and Keji ribao (Science and Technology Daily), July 4th 2002.

65. Some suspect that Linux software users would eventually switch back to the Microsoft products. See Beijing qingnian bao (Beijing Youth Daily), March 12th 2002, p. 36. 66. Ershiyi shiji jingji daobao (21st Century Economic News), July 12th 2002, and Zhongguo jingji shibao (China Economic Times), August 4th 2002.

67. Suttmeier and Yao, "China's Post-WTO Technology Policy", op. cit.

68. Xiongjian Liang and Kaisheng Ding, "Manufacturing Industry" in Jintong Lin, Xiongjian Liang, and Yan Wan (eds.), Telecommunications in China: Development and Prospects, Huntington, NY, Nova Science Publishers, 2001, pp. 75-98; Xiaobai Shen, The Chinese Road to High Technology: A Study of Telecommunications Switching Technology in the Economic Transition, New York, St. Martin, 1999; Zixiang Alex Tan, "Product Cycle Theory and Telecommunications Industry: Foreign Direct Investment, Government Policy, and Indigenous Manufacturing in China", Telecommunications Policy, Vol. 26, No. 1, 2002, pp. 17-30.

69. Zixiang Alex Tan, "Product Cycle, Wintelism, and Cross-National Production Network (CPN) for Developing Countries: China's Telecom Manufacturing Industry as a 
Case", INFO: The Journal of Policy, Regulation and Strategy for Telecommunications, Vol. 4, No. 3, 2002, pp. 57-65.

70. Tan, "Product Cycle Theory and Telecommunications Industry", op. cit.

71. See, for example, Linsu Kim, Imitation to Innovation: The Dynamics of Korea's Technological Learning, Boston, MA, Harvard Business School Press, 1997.

72. Jin W. Cyhn, Technology Transfer and International Production: The Development of the Electronics Industry in Korea, Cheltenham, UK, Edward Elgar, 2002.

73. Linsu Kim, "Pros and Cons of International Technology Transfer: A Developing Country's View", in Tamir Agmon and Mary Ann Von Glinow (eds.), Technology Transfer in International Business, New York, Oxford University Press, 1991, pp. 223-239.

74. Alberto Gabriele, "S\&T Policies and Technical Progress in China's Industry", Review of International Political Economy, Vol. 9, No. 2, 2002, pp. 333-373.

75. Jay B. Barnet and Barry Baysinger, "The Organization of Schumpeterian Innovations", in Michael W. Lawless and Luis R. Comez-Mejia (eds.), Strategic Management in High Technology Firms (Monographs in Organization Behavior and Industrial Relations, Vol. 12, Greenwish, CT, JAI Press, 1990, pp. 3-14.

76. Lianhe zaobao (Singapore), March 11th 2002, p. 17; Nanfang zhoumo (Nanfang Weekend), March 28th 2002; and Beijing Chengbao (Beijing Morning Post), April 22nd 2002. 77. See, for example, James F. Gibbons, “The Role of Stanford University: A Dean's Reflections", in Chong-Moon Lee, William F. Miller, Marguerite Gong Hancock, and Henry S. Rowen (eds.), The Silicon Valley Edge: A Habitat for Innovation and Entrepreneurship, Stanford, CA, Stanford University Press, 2000, pp. 200-217; Hiroyuki Odagiri and Akira Goto, “The Japanese System of Innovation: Past, Present, and Future", in Richard R. Nelson (ed.), National Innovation Systems: A Comparative Analysis, New York, Oxford University Press, 1993, pp. 76-114; and Linsu Kim, "National System of Industrial Innovation: Dynamics of Capability Building in Korea", in Nelson (ed.), National Innovation Systems, op. cit., pp. 357-382.

78. For a recent case in which the U.S. Semiconductor Industry Association sought federal assistance to help create and fund a Nanoelectronics Research Institute, see Don Clark, "U.S. Chip Makers Want to Create Research Institute", Asian Wall Street Journal, June 11-13th 2004, p. M8. 